hold a meeting at Lisbon in April that its members might "personally test the medicines which had been advanced as preventives of seasickness." I prepared the paper rather hastily while absent from San Francisco and without having access to $m y$ former paper, in order that it might be submitted to the International Medical Congress at its meeting.

While making corrections I desire to draw attention to a grammatical error on the second page of the paper. Per orem should be per os.

A. C. Girard, M.D.

\section{Triplets Living Over Eighty Years.}

Wrightsvillee, PA., Aug. 1, 1906.

To the Editor:-In TiIE Journal, July 28, Dr. John I. Davis, Cincinnati, speaks of triplets alive at the age of 47 , and states that so far as he knows this record is unequaled. In this connection I would say that at Manchester, York County, Pa., on Dec. 3, 1903, there died the last of a set of triplets aged 86 years, 10 months and 6 days. The other two died at the ages of 84 ana 80 , respectively. This remarkable trio was of German ancestry, of the name of Strickler, a common name in this part of the country. David, the brother, was born last and died first. One sister, Lena, the second born, died second, while Mary, the frrst born, survived the longest. These people lived quietly and peacefully in the country engaged in agrieultural pursuits, which probably added to their longevity. In this case triplets survived to the eightieth year and over. If any reader of TIIE JounNal can report anything equaling or exceeding this it will make interesting reading.

B. A. HoOver, M.D.

\section{Qualifications and Reciprocity as Viewed by the Illinois Board.}

[Editor's Note: Dr. James A. Egan, Springfield, calls attention to a typographical error in his letter, which was published in Tre Journat, August 4. On page 374, line 17, for 1889 read 1899 . Nine lines below the same error is repeated. -ED.]

Detroit, Aug. 4, 1906.

To the Elitor:-When I referred to the "disturbed periods" of my worthy brother Egan of Illinois, in my communication to TIIE Jotrnal, published July 21, I did not anticipate in the least that your readers would be furnished with so com. plete a demonstration of the affliction so mildly suggested by me. I am truly sorry, not for myself, as I am immune, but for those of your readers who do not enjoy personalities and recriminations.

In my letter I criticised the action of the Illinois State Board of Health in resigning from the American confederation from the standpoint of the reasons given for such resignation and of its subsequent action in passing regulations and qualifications exactly a counterpart of the qualifications of the confederation objected to, and forming the basis for disagreement.

I also criticised the Illinois board for its usurpation of the functions of the state legislature in granting exemption to a class of practitioners under the excuse of reciprocity when the act of reciprocity is impossible per se. I also asked Dr. Egan to formulate some rule by which a physician of national reputation could be defined by executive officers less fortunate in observation qualities than himself.

I merely referred to Qualification 2 of the American confed. eration with the statement that some fifteen states not only believe in the virtue of this qualification but also had adopted it. In his reply Dr. Egan very cautiously refuses to discuss the material questions and contents himself with a very irrelevant abuse of Qualification 2, the Michigan State Board of Registration in Medicine, and my humble self as secretary of such board.

Now, the Michigan board (and myself as its secretary) was and is entirely immaterial to our controversy. My communication was signed as secretary of the American confederation, in which Dr. Egan's board has membership, and I made no reference in my letter either to Michigan or to the
Michigan board. It certainly was within my right to criticise a board in membership, especially so when the reasons given for this board's withdrawal from membership on their face, appeared inconsistent and not in accord with the facts.

As my letter had absolutely no reference to the Illinois or Michigan boards, nor to Dr. Egan or myself as executive offcers of such boards, outside of the membership of our respective boards in the confederation, and as Dr. Egan refuses to discuss the questions raised by me on their merits and insists on denouncing the shortcomings of my board and myself, with which your readers at this time are not especially interested, I can only say in a general way, that Dr. Egan's statements regarding my official acts are not based on facts and his conclusions are unwarranted in the light of such facts; I can only ask, in justice to myself and the cause I represent, that your readers review together my letter and Dr. Egan's reply to it. I am content to rest my contentions on such a review.

Dr. Egan fails to see the analogy between the present prerequisite of the confederation, which states that an applicant for reciprocity at the discretion of either board may file proof of nembership in a recognized medical society, and that such membership may be considered in connection with the other evidences of character presented and the Illinois requirement of letters of recommendation with regard to the moral, professional and ethical character of the applicant, from a state, district, county or city medical society in the state from which the applicant comes. He states that he must decline to insult the intelligence of readers of Time Journal by attempting to recognize a material distinction in the above optional requirements.

The trouble with Dr. Egan seems to be that he is unable to distinguish the difference between the "may" and "shall," for he states that the prerequisite makes it incumbent on an applicant to show proof of membership in a medical society, and that a comparison of the two requirements will make the distinction quite apparent. Taking for granted that the prerequisite requirement of membership in a state society was expressed by the word "shall" instead of "may," this would not consistently give a reason for the withdrawal of a board in membership from the fact that it is impossible to formulate a qualification acceptable to all states in membership, and in addition the qualifications of the confederation are advisory, not mandatory.

Dr. Egan's statement that I had expressed an opinion that the prerequisite is unconstrtutional is not based on fact. I pronounced the mandatory qualification of membership in a state society, introduced by Dr. McCormack as unconstitutional, but $I$ had no support in this contention from Dr. Egan, who was present. This mandatory qualification was not adopted by the confederation.

Dr. Egan refuses to enlighten me and other executive officers as to the method employed by his board in measuring a physician of national reputation, and also declines to discuss the action of his board in usurping the authority of the legislature and tells me that it is none of my business. I accept his courteous explanation as the only rational method in justification of the action of his board.

In a question as large and intricate as that of reciprocity some degree of consideration must be shown by states, otherwise it would be impossible to accomplish results, and results have been accomplished by the American confederation in an extraordinary degree, over one thousand certificates having already been endorsed through its administration during the past four years.

My valiant and bellicose brother Egan challenges me to meet him and his big brother, the president of his board, at a future unofficial meeting of his personal friends, and to repeat some of the unkind criticisms I have felt it my duty to subscribe to in my former letter, and he states that I have neglected the opportunity of expressing my opinion of his official acts at former meetings at which he was present. Dr. Egan must remember, however, that these meetings were held prior to the date on which he joined the United States Army, Navy 
and Marine-Hospital Service through reciprocity, and that previous to this event $I$ had never taken him seriously from a strictly reciprocity point of view. In all other questions we harmonize exactly.

B. D. HaRison, Secretary.

\section{Hay-Fever Treatment by Dunbar's Remedies (Pollantin).}

Baltimore, Aug. 5, 1906.

To the Editor:-Permit me to endorse Dr. Ingals' report of results with pollantin, published in The Journal, August 4, page 376. J summarized the literature and claims of hay-fever antitoxin in the Maryland Medical Journal, August, 1904. This article was misquoted and exploited in the lay press in favor of the serum. I wrote to Messrs. Fritche \& Bros. and told them that my actual experience with the powder was practically a failure and that at an early opportunity I should collect these cases and send them to The JournaL. Other matters more pressing have prevented me. When I saw Dr. Ingals' letter I hastily examined ten histories of those who had conscientiously tried pollantin. Eight were absolutely not improved, one claimed some benefit, and the other said he was free from attacks on some days and not on others.

LeONand K. Hirshberg.

IndIANAPOLIS, Aug. 6, 1906.

To the Ealitor:- I can heartily agree with all that Dr. Ingals has stated concerning pollantin. A year ago I reported two sets of har-fever cases, one treated by pollantin and the other by the use of quinin locally in the form of a saturated solution sprayed into the nose and followed by an ointment of the same drug, as recommended by Helmholtz many years ago. My success with the simple quinin preparation was greater than with pollantin. I regard the literature accompanying the preparation very objectionable; it is impossible to prescribe pollantin for the patient without him learning all about the remedy he is using.

John F. BarniliL.

\section{Marriages}

Fraxk Donato Burss, M.D., Chicago, at Shellsburg, Iowa, July 18.

W. O. McBride, M.D., Joliet, Ill., to Miss Nannie Francis of Lima, Ohio, June 20.

Andrew P. Convwalt, M.D., to Anxa S. Maridn, M.D., both of Boston, July 22.

Aloysius J. Lenxon, M.D., Joliet, Ill, to Miss Rose Finlen of Streator, Ill., June 20.

Haydon Rochester, M.D., to Miss Mary Thomas, at Rochester, N. Y., July 31 .

Walter Walton Winte, M.D., to Miss Lenore Griffith Doyle, both of Baltimore, August 1.

Isaac Clark Gary, M.D., Chicago, to Miss Emma G, Bollinger of Kahoka, Mo., August 1.

Roy Hayman McKay, M.D., Milton, W. Va., to Miss Edna Myna Riley of Cincinnati, May 9.

Charles O. Nerms, M.D., Taylorville, Ill., to Miss Cora T. Allen of Rock Island, Ill., July 26.

George M. Kline, M.D., Ann Arbor, Mich., to Miss Ethes Fry of Grand Rapids, Mich., June 23.

Charles Pern Robbins, M.D., to Miss Frances Lyon Sinclair, both of IVinona, Minn., July 28.

Alexander H. Rouss, M.D., Kabletown, W. Va., to Miss Anna M. Stough, at York, Pa., July 26.

Francis G. Swedexburg, M.D., Rock Elm, Wis., to Miss Olive Eggleston of Red Wing Minn., July 25.

H. C. Manning, M.D., Flat Lick, Ky., to Miss Dora Smith of Booneville, $\mathrm{Ky}$, at London, $\mathrm{K}_{y}$., June 2, 1905.

Ralpi H. Parker, M.D., Storm Lake, Iowa, to Miss Ethel Sawyer Ranney of Koshkonong, Wis., August 2.

Schuyler J.oTT, M.D., Bellona, N. Y., to Mrs. M. Cornelia Hopkins of Fayette, N. Y., at Seneca Falls, N. Y., July 26.

Wili.iam H. Nevmann, M.D., Lewiston, Minn., to Miss Bernice Holt of Utica, Minn., at Winona, Minn., July 18.

\section{Deaths}

Alexander Hutchins, M.D. New York Medical College, New York City, 1860; surgeon in the United States Navy from 1861 to 1863 ; from 1876 to 1879 president of the Kings County Medical Society, and in 1883 president of the Medical Society of the State of New York, of which he was a life member, senior consulting surgeon to the Brooklyn Hospital, consulting physician to St. John's, St. Mary's and Long Island Collegre Hospital, instrumental in the foundation of the official journal of the Kings County Medical Society and its reading rooms and library, died at his home in Brooklyn, July 30, after a brief illness, aged 71 .

William Partridge Brandegee, M.D. College of Physicians and Surgeons in the City of New York, 1889; instructor in otology, University and Bellevue Hospital Medical College, senior assistant surgeon to the New York Eye and Ear Infirmary, a member of the American Laryngological, Rhinological and Otological Society, New York State Medical Society, Medical Society of New York County, Medical Association of Greater New York, Otological Society of New York, and Bellevue Medical College Society, died suddenly at his home in New York City, July 30, from cerebral hemorrhage, aged 42 .

Robert Mills Whitefoot, M.D. University of Georgetown Medical Department, Washington, D. C., 1866, a member of the American Medical Association; a pioneer physician of Bozeman, Mont.; a reteran of the Civil War and after the war a member of the medical corps of the Army; for one term surgeon general of Montana; for three years a member of the State Board of Medieal Examiners, and for many years health officer of Bozeman, died at the Bozeman Sanitarium, July 25 , from Bright's disease, after a long and severe illness, aged 66 .

Josiah Giddings, M.D. Castleton (Vt.) Medical College, 1856; a surgeon during the Civil War, and a member of the Harrison County (Iowa) Medical Society, died recently at his home in Woodbine, Iowa. At a remular meeting of the Harrison County Medical Society held at Missouri Valley Iowa, July 19, resolutions were adopted expressing regret at the death of Dr Giddings and sympathy with his family.

Alexander Memelsdorf, M.D. University of Würzburg, Germany, 1881; some-time staff surgeon in the German Army, professor of dermatology and venereal diseases in the Illinois Medical College, a member of the American Medical Association; a respected practitioner and a successful teacher, died at his home in Chicago, May 18, from heart disease, after an illness of one year, aged 47 .

Louis H. Willard, M.D. Hahnemann Medical College, Philadelphia, 1866, of Pittsburg, Pa., for forty years a member of the staff of the Pittsburg Homeopathic Hospital; a surgeon in the Navy during the Civil War, and at the time of his death president of the State Board of Medical Examiners, died suddenly at his summer home in Beaumaris, Ont., July 30 , aged 66 .

Edmond Church Ingalls, M.D., Rush Medical College, 1894 , but never a practitioner of medicine, formerly a resident of Oak Park, Ill., for many years a sufferer from sciatica, on account of which he had acquired the habit of drug use, which he had repeatedly tried to overcome, died in the Shirley Hotel, Denver, Colo., August 1, from an overdose of cocain, aged 38.

Jessie Maclarin McGregor, M.D. University of Edinburgh, Scotland, a member of the Medical Society of the City and County of Denver, and an instructor and clinical teacher in the departments of pathology and gynecology in Denver and Gross Medical College, Denver, died at her home in Denver, March 22 , from cerebrospinal meningitis, after an illness of four days.

Wilbur Alexander, M.D. Medical College of Ohio, Cincinnati, 1893, a specialist on diseases of the eye, ear, nose and throat, oculist of the Toledo, St. Louis and Western railroad; a member of the Clinton County and of the Indiana State Medical Society, died suddenly at his home in Frankfort, Ind., from angina pectoris, July 23 , aged 36 .

Charles F. Herman, M.D. Long Island College Hospital, Brooklyn, 1898; a member of the American Medical Association and Kings County Medical Society, physician to the Brooklyn Dispensary and Polhemus Memorial Clinic, a resident of Brooklyn, died in Waterbury, Conn., August 2.

Samuel H. Frank, M.D. University of Maryland School of Medicine, Baltimore, $\mathbf{1 8 6 2}$, of Baltimore, a specialist on diseases of the eye and ear, president of the Hebrew Hospital and Asylum, died suddenly at Chattolanee Springs, Baltimore County, Md., August 3, from heart disease, aged 65 . 